\title{
Fastlegetilhørighet og sykefravær - en registerbasert studie
}

BAKGRUNN Forskning på fastlegenes rolle i sykefraværet er metodisk utfordrende, og resultatene spriker. Vi undersøkte hvordan langtidssykefraværet påvirkes av legeog listekarakteristika.

MATERIALE OG METODE Studien omfattet alle yrkesaktive bosatt i Oslo og Bergen i 2005-06 med samme fastlege gjennom hele 2006 ( $N=298$ 039). Krypterte data om individenes sykefravær i 2006, alder, kjønn og utdanning ble koblet med data om fastlegene ( $N=568$ ) og pasientlistene og analysert med logistisk regresjon. Utfallet var minst ett sykefravær betalt av Nav. Forklaringsvariablene var fastlegenes alder, kjønn, listelengde og listestatus låpen/ lukket) og variabler som karakteriserer pasientlistenes sammensetning. Analysene ble stratifisert etter kjønn og kontrollert for individets alder og utdanning.

RESULTATER Fastlegenes alder, kjønn og listelengde var ikke assosiert med sykefravær betalt av Nav. Sannsynlighet for sykefravær > 16 dager ble redusert for både kvinner og menn når listen inneholdt mange høyt utdannede, høy andel eldre og få uførepensjonister. Menn på lister med høy andel menn og lister med høy andel yrkesaktive hadde også lavere odds for sykefravær > 16 dager. For kvinner var sykefraværet lavere ved åpne lister enn ved lukkede lister.

FORTOLKNING I tillegg til velkjente individuelle faktorer viser studien at sannsynligheten for sykefravær påvirkes av den sosiodemografiske sammensetningen av fastlegelisten man tilhører.

Utskrivning av sykmeldinger er en viktig oppgave for leger $(1,2)$. I Norge står fastlegene for omtrent $70 \%$ av alle sykmeldinger (3). I en spørreundersøkelse blant norske fastleger fra 2010 oppga $38 \%$ at de hadde mer enn 20 sykmeldingsrelaterte konsultasjoner hver uke, mens $58 \%$ hadde slike konsultasjoner 6-20 ganger per uke (4). Både i Norge og internasjonalt har man undersøkt hvordan leger håndterer sykmeldingsoppgaven $(1,5)$. Sykmeldingsforskning er metodisk utfordrende, og kunnskapsgrunnlaget er svakt (1).

I kvalitative studier (6-8) og spørreskjemaundersøkelser blant leger (4, 9-11) rapporteres mange problemer knyttet til sykmeldingsoppgaven $(4,6,11)$. I vignettstudier med papirkasus eller videoopptak der leger bedømmer behov for sykmelding $(8,12)$ er det stor enighet når tilfellene er veldefinerte (12), men sprik når sykdomstilstandene er uklare (8). Dette gjelder særlig når man sammenlikner leger fra ulike land $(12,13)$. Hyppigheten av sykmelding er studert med praksisdata knyttet til diagnoser eller pasientgrupper $(5,13,14)$. Begrepet sykmeldingsrater defineres ulikt og gjør sammenlikning av studier vanskelig (2). I tillegg har legene ulikt antall konsultasjoner per dag, ulik tilgjengelighet ved akutte tilstander, og pasientgrunnlaget varierer. I andre studier har man funnet at legene er presise når det gjelder å forutsi lengden på sykefraværet (15).

I Norge gir nasjonale trygderegistre gode muligheter for epidemiologiske studier av sykefraværet. Fastlegenes sykmeldings- praksis kan studeres ved å koble trygderegistrene med fastlegeregisteret som inneholder data om legene, listelengder og listesammensetning.

Det er to registre som brukes i sykmeldingsforskning: Navs sykmeldingsregister og Navs sykepengeregister.

Sykmeldingsregisteret omfatter alt legemeldt fravær basert på innsendte sykmeldinger. $65 \%$ av sykmeldingene gjelder fravær under 17 dager som vanligvis dekkes av arbeidsgiver (16). Nav identifiserer diagnoser og sykmelders identitet. Det skilles ikke mellom fastlegenes sykmeldinger av egne og andres pasienter eller om det skjedde på legevakt (3).

To sentrale studier av norske fastlegers sykmeldingspraksis har brukt sykmeldingsregisteret koblet med fastlegeregisteret: Brage \& Kann fant at eldre fastleger sykmeldte mer enn yngre, spesialister mer enn ikke-spesialister og at sykmeldingsfrekvensen økte med økende listelengde. Mannlige leger skrev ut flere sykmeldinger for sine pasienter enn kvinnelige leger. Personer på kvinnelige legers lister var imidlertid mer sykmeldt enn personer på mannlige legers lister, justert for pasientenes kjønn og alder (3). Marcussen og medarbeideres studie (17) påviste at personer med kvinnelig fastlege, ung fastlege og fastlege med kortere liste var minst sykmeldt, men forskjellene var små.

Navs sykepengeregister er en del av Statistisk sentralbyrås forskningsdatabase FD-trygd. Det viser hva Nav faktisk har

\author{
Lee Winde \\ Inger Haukenes \\ $\emptyset y s t e i n$ Hetlevik \\ Sturla Gjesdal \\ sturla.gjesdal@isf.uib.no \\ Forskningsgruppe for sosial epidemiolog \\ Institutt for samfunnsmedisinske fag \\ Universitetet i Bergen \\ D \\ Engelsk oversettelse på www.tidsskriftet.no \\ e-tab 3 finnes i Tidsskriftets elektroniske utgaver. \\ > Se også side 6

\section{HOVEDBUDSKAP} \\ Fastlegens kjønn, alder og listelengde \\ påvirket ikke odds for sykefravær > 16 dager \\ blant yrkesaktive i Oslo og Bergen
}

$\AA$ A tilhøre fastlegelister med høy sosioøkonomisk status reduserte sannsynlighet for sykefravær

Kvinner på åpne lister hadde lavere odds for sykefravær enn på lukket liste 
utbetalt i sykepenger, i hovedsak sykefravær over 16 dager, relatert til diagnose og pasientenes sosiodemografiske karakteristika. Sykmelders identitet finnes ikke i dette registeret, men når det kobles med fastlegeregisteret fremkommer de sykmeldtes fastlegetilknytning. Siden registeret bare omfatter sykefravær der sykepenger faktisk er utbetalt av Nav, anses validiteten som høy $(16,18)$. Aakvik og medarbeidere brukte sykepengeregisteret koblet med fastlegeregisteret $i$ en flernivåmodell. De fant at legefaktorer hadde en marginal effekt som årsak til variasjoner i sykefraværet sammenliknet med individuelle faktorer (19).

I en tidligere studie, som to av oss var med på, inkluderte vi data fra sykepengeregisteret for å beskrive hvordan antall sykefraværsdager varierte i ulike befolkningsgrupper etter pasientenes alder, kjønn og utdanningsnivå, etter fastlegens kjønn og alder samt ulik kjønnsfordeling og ulik andel uførepensjonister på listene. Antall fraværsdager varierte i hovedsak ikke med fastlegekarakteristika, men gjennomsnittlig antall sykemeldingsdager økte i alle grupper med høyere andel uførepensjonister på fastlegelisten pasienten tilhørte (20). I studien som presenteres her bruker vi samme datamateriale, men inkluderer flere variabler som karakteriserer listesammensetningen. Ved hjelp av logistisk regresjon analyserer vi om egenskaper ved fastlegen og listesammensetningen påvirker sannsynligheten for at legens listepasienter blir sykmeldt over 16 dager.

\section{Materiale og metode}

Data

Studien omfatter alle som var yrkesaktive (lønnsinntekt $>1 \mathrm{G}$ ) i aldersgruppen 20-66 år, bosatt i Oslo og Bergen i 2005-06, og som hadde samme fastlege 1.1.2006 og 31.12. 2006, totalt 143624 kvinner og 154415 menn. Data om individenes alder, kjønn, yrkesaktivitet, utdanningsnivå og sykefravær betalt av Nav i 2006 ble hentet fra FD-trygd. Fra fastlegeregisteret fikk vi informasjon om individenes fastlegetilknytning og data om fastlegenes kjønn, alder, spesialiststatus, listelengde og om listen var åpen eller lukket. Statistisk sentralbyrå koblet de to datasettene, og disse ble utlevert i kryptert form. 568 fastleger inngikk i studien. Sosiodemografiske data fra FD-trygd ble også aggregert på listenivå og benyttet for å karakterisere sammensetningen av listepopulasjonene. Bruk og kobling av data var godkjent av registereierne og Datatilsynet.
Tabell 1 Oversikt over studiepopulasjonen, yrkesaktive kvinner og menn 20-66 år, bosatt i Oslo og Bergen i 2005-6, og karakteristika ved deres fastleger og de pasientlistene de er tilknyttet

$\begin{array}{ccc}\text { Totalt } & \text { Kvinner } & \text { Menn } \\ (\mathrm{N}=298039) & (\mathrm{n}=143624) & (\mathrm{n}=154415)\end{array}$

\section{Individdata}

$\begin{array}{lccc}\text { Gjennomsnittsalder i år (SD) } & 43(0,02) & 42(0,03) & 43(0,03) \\ \text { Utdanning } \geq 16 \text { år (\%) } & 43 & 46 & 41 \\ \text { Minst ett sykefravær betalt av Nav i 2006 (\%) } & 17,2 & 22,2 & 12,5\end{array}$

Fastlegetilknytning

Mannlig fastlege (\%)

69

79

Gjennomsnittsalder fastlegene (SD)

$51(0,01) \quad 50(0,02)$

$51(0,02)$

\section{Fastlege man tilhører}

Gjennomsnitt antall pasienter på listen (SD) $1427(0,67) \quad 1424(0,95) \quad 1430(0,95)$

Andel tilknyttet lukket liste $(\%)$

$55 \quad 61 \quad 50$

Andel mannlige pasienter på listen $[\%]$

49

46

Andel yrkesaktive i listepopulasjonen $20-67$ år (\%)

Andel med utdanning $\geq 16$ år $(\%)$

43

72

71

Andel uførepensjonister i listepopulasjonen $20-67$ år $(\%)$

Andel $\geq 67$ år på listen (\%)

46

40

$8 \quad 8 \quad 8$

11

8

11

Tabell 2 Sammenheng mellom sykefravær > 16 dager og personens alder og utdanningsnivå. Logistisk regresjonsmodell med $N=143624$ yrkesaktive kvinner og 154415 yrkesaktive menn bosatt i Oslo og Bergen i 2005-06. OR = odds ratio, $\mathrm{KI}=$ konfidensintervall

$\frac{\text { Kvinner }}{\text { Antall } \quad \text { OR }(95 \% \mathrm{KI})} \frac{\text { Menn }}{\text { Antall }}$ OR (95\% KI)

\section{Pasientens alder}

$\begin{array}{lllll}20-34 \text { år } & 39456 & 1 & 41556 & 1 \\ 35-49 \text { år } & 59920 & 0,98(0,95-1,01) & 65152 & 1,29(1,24-1,34) \\ \geq 50 \text { å } & 44248 & 1,06(1,03-1,10) & 47707 & 1,59(1,53-1,66) \\ P \text { for trend } & & <0,001 & <0,001\end{array}$

\section{Pasientens utdanningsnivå}

\begin{tabular}{lllll}
$<16$ år & 78249 & 1 & 91142 & 1 \\
$\geq 16$ år & 65375 & $0,84(0,82-0,87)$ & 63273 & $0,48(0,47-0,50)$ \\
$P$ & & $<0,001$ & $<0,001$ \\
\hline
\end{tabular}


Statistisk analyse

Utfallsvariabelen var om et individ hadde minst ett sykefravær betalt av Nav i studieperioden. I hovedsak gjelder dette fraværstilfeller over 16 dager. I artikkelen bruker vi betegnelsen «minst ett sykefravær $>16$ dager».

Individenes kjønn, alder og utdanningsnivå er kjente prediktorer for sykefravær og ble inkludert som forklaringsvariabel i alle analysemodeller. Alder ble delt inn i kategoriene 18-34 år, 35-49 år og $\geq 50$ år (tab 1). Alderskategoriene gjenspeiler at risiko for sykefravær øker med økende alder, og denne kategoriseringen var også brukt i en tidligere studie (20). Høyeste fullførte utdanningsnivå ble dikotomisert etter om man hadde universitets- eller høyskoleutdanning eller ikke ( $<16$ år og $\geq 16$ år). Vi antok at dette skulle gi betydelig forskjell i odds for sykefravær.

Andre forklaringsvariabler var fastlegenes alder (10-årsaldersgrupper), kjønn, spesialiststatus, listelengde (intervaller på 250 pasienter) og om fastlegens liste var åpen eller lukket. Disse er også brukt i tidligere studier $(3,17,20)$.

I tillegg inkluderte vi følgende variabler som karakteriserer listens sosiodemografiske sammensetning: Andel menn, andel yrkesaktive, andel med høyere utdanning, andel uførepensjonister og andel eldre over 67 år. Listene ble kategorisert i kvartiler i samsvar med disse variablene.

Alle disse forklaringsvariablene hadde statistisk signifikant effekt $\mathrm{i}$ univariat analyse, unntatt spesialiststatus, som ble tatt ut av videre analyser. Betydningen av de ulike forklaringsvariablene ble undersøkt ved hjelp av multivariat logistisk regresjon med oddsrater (OR) og tilhørende 95\% konfidensintervall (95\% KI). Regresjonsmodellen forutsetter at legevariabler og listesammensetningen påvirker sykefraværstilbøyelighet, og ikke omvendt.

Analysene ble gjort for kvinner og menn separat, siden tidligere forskning har vist store kjønnsforskjeller i sykefraværet (18).

Først analyserte vi betydningen av individenes alder og utdanning (tab 2). I e-tabell 3 inkluderte vi i tillegg legenes alder og kjønn, listelengde og om fastlegens liste var åpen eller lukket. I den siste analysen (tab 4) inkluderte vi også variablene knyttet til listesammensetning. $P$ for trend er angitt med unntak av dikotome variabler.

Legefaktorer som ikke fanges opp av tilgjengelige variabler, f.eks. standard på kontorlokaler og telefontilgjengelighet, kan også ha innvirkning på sykefraværet $\mathrm{i}$ listepopulasjonen. Alle analysene er derfor gjort i en tonivåmodell som ytterligere korrigerer for dette (clustering).

\section{Resultater}

Tabell 1 viser hvordan studiepopulasjonen fordelte seg på sosiodemografiske variabler, ulike typer fastleger og listekarakteristika. I studieperioden hadde $22,2 \%$ av kvinnene
Tabell 4 Sammenheng mellom sykefravær > 16 dager, karakteristika ved pasientens fastlege og karakteristika ved pasientlisten personen tilhører. Resultat av logistisk regresjon, justert for personens alder, kjønn og utdanning. $N=143624$ yrkesaktive kvinner og 154415 yrkesaktive menn bosatt i Oslo og Bergen i 2005-06. OR = odds ratio, $\mathrm{KI}=$ konfidensintervall

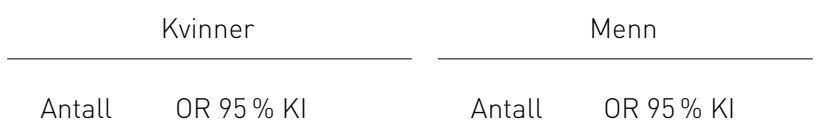

\section{Legevariabler}

Legens kjønn

$\begin{array}{lllrl}\text { Kvinne } & 60216 & 1 & 33159 & 1 \\ \text { Mann } & 83408 & 1,00(0,92-1,07) & 121256 & 1,07(0,97-1,18) \\ P & & 0,921 & & 0,168\end{array}$

\section{Legens alder}

$\begin{array}{lllll}<40 \text { år } & 10972 & 1 & 12179 & 1 \\ 40-49 \text { år } & 47160 & 1,01(0,94-1,08) & 49436 & 0,96(0,87-1,05) \\ 50-59 \text { år } & 72292 & 0,99(0,92-1,06) & 75034 & 0,98(0,89-1,07) \\ \geq 60 \text { år } & 13200 & 1,01(0,92-1,11) & 17766 & 1,04(0,93-1,16) \\ P \text { for trend } & & 0,578 & & 0,156\end{array}$

\section{Listelengde}

$\begin{array}{lllll}<1000 & 15895 & 1 & 17484 & 1 \\ 1000-1249 & 30182 & 1,01(0,95-1,08) & 32106 & 1,01(0,94-1,09) \\ 1250-1499 & 48648 & 1,04(0,98-1,10) & 48295 & 1,03(0,96-1,11) \\ 1500-1749 & 25562 & 1,03(0,96-1,10) & 29619 & 1,03(0,95-1,12) \\ \geq 1750 & 23337 & 1,01(0,94-1,08) & 26911 & 1,04(0,95-1,13) \\ P \text { for trend } & & 0,387 & & 0,548\end{array}$

Listestatus

$\begin{array}{lllll}\text { Apen } & 56210 & 1 & 76837 & 1 \\ \text { Lukket } & 87414 & 1,05(1,01-1,09) & 77578 & 1,03(0,98-1,08) \\ P & & 0,021 & & 0,241\end{array}$

Listesammensetning

Andel menn på listen

$\begin{array}{lllll}<42 \% & 47340 & 1 & 20418 & 1 \\ 42-52 \% & 40302 & 1,06(0,99-1,14) & 38437 & 0,94(0,86-1,03) \\ 52-57 \% & 32425 & 1,03(0,94-1,12) & 45887 & 0,91(0,81-1,02) \\ >57 \% & 23557 & 0,95(0,86-1,04) & 49673 & 0,87(0,77-0,98) \\ \text { P for trend } & & 0,013 & & <0,001\end{array}$

Andel med utdanning $\geq 16$ år

$\begin{array}{lllll}<21 \% & 36328 & 1 & 41102 & 1 \\ 21-29 \% & 32787 & 0,90(0,85-0,95) & 39211 & 0,89(0,83-0,95) \\ 29-36 \% & 35376 & 0,84(0,80-0,90) & 40753 & 0,84(0,78-0,90) \\ >36 \% & 39133 & 0,78(0,78-0,83) & 33349 & 0,75(0,69-0,81) \\ \text { P for trend } & & <0,001 & & <0,001\end{array}$


Tabell 4, forts. Sammenheng mellom sykefravær > 16 dager, karakteristika ved pasientens fastlege og karakteristika ved pasientlisten personen tilhører. Resultat av logistisk regresjon, justert for personens alder, kjønn og utdanning. $N=143624$ yrkesaktive kvinner og $154415 \mathrm{yr}$ kesaktive menn bosatt i Oslo og Bergen i 2005-06. OR = odds ratio, $\mathrm{Kl}=$ konfidensintervall

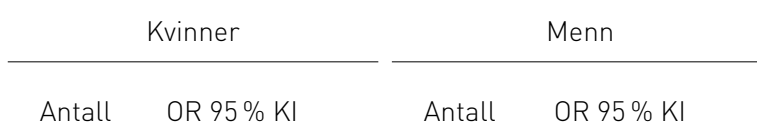

Listesammensetningen ${ }^{1}$, forts.

Andel yrkesaktive blant 20-67 år

$\begin{array}{lllll}<68 \% & 24757 & 1 & 34987 & 1 \\ 68-72 \% & 36327 & 1,01(0,95-1,06) & 43480 & 0,90(0,84-0,96) \\ 72-75 \% & 39209 & 0,96(0,91-1,02) & 41028 & 0,81(0,75-0,87) \\ >75 \% & 43331 & 0,97(0,91-1,03) & 34900 & 0,86(0,80-0,93) \\ P \text { for trend } & & 0,107 & & <0,001\end{array}$

Andel uføre blant 20-67 år

$\begin{array}{lllll}<5 \% & 37092 & 1 & 39479 & 1 \\ 5-8 \% & 36725 & 1,08(1,02-1,14) & 38708 & 1,14(1,06-1,23) \\ 8-10 \% & 35290 & 1,18(1,10-1,26) & 38048 & 1,21(1,11-1,31) \\ >10 \% & 34517 & 1,20(1,11-1,30) & 38180 & 1,27(1,15-1,40) \\ P \text { for trend } & & <0,001 & <0,001\end{array}$

Andel $\geq 67$ år

\begin{tabular}{lllll}
$<6 \%$ & 36088 & 1 & 37102 & 1 \\
$6-11 \%$ & 36033 & $0,98(0,93-1,03)$ & 37191 & $0,95(0,89-1,01)$ \\
$11-15 \%$ & 38112 & $0,91(0,86-0,97)$ & 39330 & $0,90(0,83-0,96)$ \\
$>15 \%$ & 33391 & $0,85(0,80-0,91)$ & 40792 & $0,82(0,76-0,89)$ \\
$P$ for trend & & 0,003 & $<0,001$ \\
\hline
\end{tabular}

Legelistene er gruppert i kvartiler for hver variabel som brukes for å beskrive listepopulasjonen på fastlegelisten personen tilhører

og $12,5 \%$ av mennene minst ett sykefravær $>16$ dager.

Tabell 2 viser sammenhengen mellom utdanning og alder og sykefravær $>16$ dager for kvinner og menn. E-tabell 3 viser at det å ha en mannlig fastlege økte sannsynligheten for minst ett sykefravær $>16$ dager med $5 \%$ hos kvinner. Kvinner som tilhørte lukket liste hadde $8 \%$ høyere sannsynlighet for minst ett sykefravær $>16$ dager enn dem på åpen liste. Her var det ingen signifikant forskjell for menn. Menn med fastlege over 59 år hadde $11 \%$ høyere odds enn menn med fastleger under 40 . Lengden på pasientlisten man tilhørte, hadde ingen betydning for sykefraværet.

I tabell 4, der vi også undersøkte betydningen av listesammensetning, forsvant signifikante funn knyttet til fastlegens alder og kjønn, men å tilhøre en lukket liste ga fortsatt en $5 \%$ økning av odds hos kvinner.

Oddsen for å bli sykmeldt $>16$ dager sank for både kvinner og menn ved høyere andel med utdanning $\geq 16$ år på listen personen tilhørte (10-22\% reduksjon for kvinner, $11-25 \%$ reduksjon for menn). Også det å tilhøre en liste med middels høy eller høy andel eldre over 66 år ga lavere odds for sykefravær $>16$ dager for begge kjønn.

Menn og kvinner som tilhørte lister med $>10 \%$ uførepensjonister hadde henholdsvis $27 \%$ og $20 \%$ høyere odds for å bli sykmeldt $>16$ dager sammenliknet med dem som tilhørte lister med $<5 \%$ uføre, alt annet holdt likt.

Menn som tilhørte lister med overvekt av menn, hadde $13 \%$ lavere odds for minst ett sykefravær $>16$ dager sammenliknet med menn på kvinnedominerte lister. Det samme gjaldt menn der det var større andel yrkesaktive på listen pasienten tilhørte.

\section{Diskusjon \\ Hovedfunn}

$22 \%$ av kvinnene og $13 \%$ av mennene hadde minst én sykmelding $>16$ dager. Fastlegenes alder, kjønn og listelengde var ikke assosiert med sykefravær betalt av Nav. Sannsynlighet for sykefravær $>16$ dager ble redusert for både kvinner og menn ved mange høyt utdannede, ved høy andel eldre og ved få uførepensjonister på listen. Menn som tilhørte lister med høy andel menn og lister med høy andel yrkesaktive hadde også lavere odds for sykefravær $>16$ dager. I tillegg hadde kvinner som tilhørte åpen liste lavere odds for sykefravær enn ved lukket liste.

\section{Sammenlikning med tidligere studier}

Fire tidligere studier (3, 17, 19-20) er særlig relevante, og noen av funnene har fătt bred plass i mediene (21). Våre resultater med hensyn til de enkle legevariablene (alder og kjønn) er forskjellig fra disse. Markussen og medarbeidere brukte data om alt legemeldt fravær, mens Brage og Kann studerte et utvalg av sykmeldinger som fastleger både hadde startet og avsluttet på egne pasienter $\mathrm{i}$ 2003-04. Dette utgjorde halvparten av sykmeldingene i studieperioden. Markussens studie var prospektiv og omfattet et datasett med alle sykmeldinger mottatt hos Nav fra 2001-04, mens vi brukte tverrsnittsdata fra et mindre utvalg, men med nyere data, fra 2005-06.

Våre funn er mer i tråd med Aakvik og medarbeidere som brukte data fra hele Norge og som konkluderte med at legevariablene har liten betydning (19). Liknende funn er også gjort i Storbritannia (22).

Funnene er også i tråd med resultater fra vår tidligere studie fra 2010, der samme data ble brukt (20). Vi fant da som nå liten sammenheng mellom sykefravær og fastlegevariabler, mens uføreandelen på fastlegens liste hadde sammenheng med antallet sykefraværsdager.

Unntatt kjønnssammensetning og andel uførepensjonister er våre variabler om listesammensetning ikke brukt i tidligere studier av sykefravær.

\section{Metodologiske betraktninger}

Denne studien undersøker ikke variasjoner i fastlegenes sykmeldingsrater eller hvor mange sykmeldinger en fastlege skriver ut $\mathrm{i}$ løpet av en tidsperiode. Slike studier har vært gjort tidligere både nasjonalt og internasjonalt $(2,13-14)$. I tillegg til at antall sykmeldinger avspeiler legens praksispopulasjon, avhenger antallet også av produktivitet (antall konsultasjoner per dag) og tilgjengelighet (andel av konsultasjonene som utgjøres av pasienter med akutt sykdom). Det er derfor vanskelig å avgjøre hvilken rolle legen spiller, og resultatene fra denne typen studier varierer mye.

Vi valgte derfor en epidemiologisk tilnærming der den yrkesaktive befolkningens risiko for å bli sykmeldt står i fokus. Hvilken fastlege man har, blir brukt som en av flere forklaringsfaktorer, men hvor stor del av sykmeldingene som er utskrevet av egen fastlege vet man ikke. Denne undersøkelsesmetoden er også brukt tidligere (17, 19-20).

Vi studerte bare sykefravær $>16$ dager, som er det som har størst betydning for sam- 
funnsøkonomien (16) og for utstøtningen fra arbeidslivet (23). Dette er et grovt mål på sykefravær, og hyppighet og lengde på fraværene ble ikke tatt i betraktning. Egenmeldt fravær og legemeldt fravær betalt av arbeidsgiver ble ikke inkludert $(16,18)$.

Vi valgte å bruke gjennomsnittlig utdanningsnivå og andel uførepensjonister i alderen 20-67 som indikator på sosioøkonomisk status. Her kunne andre variabler også vært benyttet.

Studien er tverrsnittsbasert, og man kan ikke sikkert utlede årsaksforhold. Imidlertid brukes et datasett med komplette data for sykefraværet dekket av Nav for yrkesaktive i de to største kommunene i Norge i et helt år.

I studier av sykefraværet i Norge er det funnet store geografiske forskjeller (24). Ved å velge to større byer, reduseres effekter av varierende legedekning i utkanter og småkommuner, og resultatene blir et mer direkte uttrykk for lege- og listeeffekter. Resultatene fra storbybefolkningen i Oslo og Bergen kan også ha større relevans i forhold til internasjonale sammenlikninger.

At studien bare inkluderte personer som var bofast i samme kommune og hadde samme fastlege i hele perioden, gjør resultatene mer presise, men reduserer generaliserbarheten noe.

Vi gjorde alle analysene for kvinner og menn separat, siden sykefraværsmønsteret er forskjellig for de to kjønn. I tillegg så vi at det er betydelige forskjeller i kvinner og menns fastlegetilknytning. $42 \%$ av kvinnene hadde kvinnelig fastlege, versus $21 \%$ for menn, og flere kvinner står på lukket liste (61\%, versus $50 \%$ av menn).

\section{Implikasjoner og behov for videre studier}

Listetilhørighet i fastlegeordningen er i prinsippet ikke geografisk basert. Det er likevel grunn til å tro at lister med lav sosioøkonomisk status tilhører leger som har sin praksis i mindre ressurssterke bydeler. En slik listesammensetning kan også indikere at fastlegen over tid har hatt en liberal praksis i forhold til sykmelding og trygd, som kan trekke til seg pasienter med stort behov for trygdeytelser.

Studien viser at den sosioøkonomiske sammensetningen av listen påvirker odds for å bli sykmeldt $>16$ dager også for dem som selv har høyere sosioøkonomisk status, målt ved utdanningsnivå. Omvendt betyr det at personer med lav utdanning som tilhører fastlegelister der gjennomsnittet har høy sosial status, blir sykmeldt sjeldnere enn tilsvarende pasienter på andre lister. Dette kan oppfattes som ulik behandling i forhold til rettigheter i folketrygden.

At yrkesaktive på lister med mange eldre (>66 år) har mindre risiko for å bli sykmeldt $>16$ dager, var et uventet funn som bør studeres videre. Den delen av befolkningen som skifter fastlege, med eller uten flytting, kan utgjøre en risikogruppe for sykmelding og bør derfor undersøkes nærmere. Bruk av andre sosioøkonomiske variabler som inntekt, yrke og eventuelt tidligere arbeidsledighet kunne ha gitt et mer fullstendig bilde.

\section{Konklusjon}

Fastlegenes rolle i sykefraværet er et kontroversielt tema som har vært mye diskutert også i mediene. Påstander om at eldre og mannlige leger sykmelder mer enn kvinnelige og unge leger har fått store overskrifter, men er sannsynligvis konfunderende fenomener som forsvinner når man justerer for listepopulasjonenes sammensetning. I tillegg er det stor forskjell om man ser på omfanget av fastlegenes utskrivning av sykmeldinger, som vil avhenge av arbeidstid, tilgjengelighet og deltakelse på legevakt, eller om man har et epidemiologisk perspektiv og studerer listepopulasjonens fravær. Resultater fra denne typen studier bør legges til grunn hvis man ønsker å monitorere og sammenlikne fastlegenes sykmeldingsaktivitet.

\section{Lee D. Winde (f. 1982)}

er master i sosiologi og ph.d.-stipendiat. Forfatter har fylt ut ICMJE-skjemaet og oppgir følgende interessekonflikter: Ph.d.-stipendiatet er finansiert av Norges forskningsråd.

\section{Inger Haukenes (f. 1957)}

er fysioterapeut og cand.philol. med hovedfag i filosofi. Hun er ph.d.-stipendiat ved Universitetet i Bergen

Forfatter har fylt ut ICMJE-skjemaet og oppgir ingen interessekonflikter.

\section{Øystein Hetlevik (f. 1958)}

er spesialist i allmennmedisin og samfunnsmedisin og ph.d.-stipendiat. Han er fastlege ved Bønes Legesenter i Bergen.

Forfatter har fylt ut ICMJE-skjemaet og oppgir følgende interessekonflikter: Ph.d.-stipendiatet er finansiert av Allmennmedisinsk forskningsfond.

\section{Sturla Gjesdal (f.1952)}

er dr. med, professor i allmennmedisin, spesialist i samfunnsmedisin og i allmennmedisin og har master of public health fra London School of Hygiene and Tropical Medicine. Han er fastlege ved Eidsvåg legekontor i Bergen. Forfatter har fylt ut ICMJE-skjemaet og oppgir følgende interessekonflikter: Instituttet har fått midler fra Allmennmedisinsk forskningsfond og Norges forskningsråd.

\section{Litteratur}

1. Wahlström R, Alexanderson K. Swedish Council on Technology Assessment in Health Care (SBU). Chapter 11. Physicians' sick-listing practices. Scand J Public Health Suppl 2004; 63: 222-55.

2. Wynne-Jones G, Mallen CD, Welsh V et al. Rates of sickness certification in European primary care: A systematic review. Eur J Gen Pract 2008; 14 99-108.

3. Brage S, Kann IC. Fastlegers sykemeldingspraksis I: Variasjoner: Rikstrygdeverket 2006

4. Winde LD, Alexanderson K, Carlsen B et al. General practitioners' experiences with sickness certifi- cation: a comparison of survey data from Sweden and Norway. BMC Fam Pract 2012; 13: 10.

5. Tellnes G. Sickness certification - an epidemiological study related to community medicine and general practice. Oslo: Department of Community Medicine, University of Oslo, 1990

6. Wynne-Jones G, Mallen CD, Main CJ et al. What do GPs feel about sickness certification? A systematic search and narrative review. Scand J Prim Health Care 2010; 28: 67-75.

7. Swartling MS, Alexanderson KA, Wahlstrom RA Barriers to good sickness certification - an inter view study with Swedish general practitioners. Scand J Public Health 2008; 36: 408-14.

8. Nilsen S, Werner EL, Maeland S et al. Considerations made by the general practitioner when dealing with sick-listing of patients suffering from subjective and composite health complaints. Scand J Prim Health Care 2011: 29: 7-12.

9. Löfgren A, Hagberg J, Arrelöv B et al. Frequency and nature of problems associated with sickness certification tasks: a cross-sectional questionnaire study of 5455 physicians. Scand J Prim Health Care 2007: 25: 178-85.

10. Gulbrandsen P, Hofoss D, Nylenna M et al. General practitioners' relationship to sickness certification. Scand J Prim Health Care 2007: 25: 20 -6.

11. Lindholm C, Arrelöv B, Nilsson $G$ et al. Sicknesscertification practice in different clinical settings: a survey of all physicians in a country. BMC Public Health 2010; 10: 752-9.

12. Halvorsen PA, Wennevold K, Fleten N et al. Decisions on sick leave certifications for acute airways infections based on vignettes: a crosssectional survey of GPs in Norway and Poland. Scand J Prim Health Care 2011; 29: 110-6.

13. Godycki-Cwirko M, Nocun M, Butler CC et al. Sickness certification for patients with acute cough/LRTI in primary care in Poland and Norway. Scand J Prim Health Care 2011; 29: 13-8.

14. Wynne-Jones G, Mallen CD, Mottram S et al. Identification of UK sickness certification rates, standardised for age and sex. Br J Gen Pract 2009 59: $510-6$

15. Reiso H, Gulbrandsen P, Brage S. Doctors' prediction of certified sickness absence. Fam Pract 2004 21: $192-8$

16. Bjerkedal T, Thune O. Hva koster sykelønnsordningen? Tidsskr Nor Lægeforen 2003; 123: 662-3.

17. Markussen S, Røed K, Røgeberg OJ et al. The anatomy of absenteeism. J Health Econ 2011: 30 . 277-92.

18. Gjesdal S. Sykefraværets utvikling i Norge 1975-2002. Tidsskr Nor Lægeforen 2005; 125 : $742-5$.

19. Aakvik A, Holmås TH, Kamrul Islam M. Does variation in general practitioner (GP) practice matter for the length of sick leave? A multilevel analysis based on Norwegian GP-patient data. Soc Sci Med 2010: 70: 1590-8.

20. Winde LD, Hansen HT, Gjesdal S. General practitioner characteristics and sickness absence-a register-based study of 348054 employed Norwegians. Eur J Gen Pract 2011: 17: 210-6.

21. Johansen PA. Snille leger gir økt sykefravær Aftenposten 30.9.2010.

22. Gabbay M. Access to welfare benefits in primary care. BMJ 2010; 341: c3642

23. Gjesdal S, Bratberg E. Diagnosis and duration of sickness absence as predictors for disability pension: results from a three-year, multi-register based* and prospective study. Scand J Public Health 2003; 31: 246-54.

24. Helde I, Kristoffersen P. Lysø, N. Kan næringsstruktur forklare fylkesvise forskjeller i sykefraværet? Arbeid og velferd 2011; nr. 3: 14-29

Mottatt 11.11. 2011, første revisjon innsendt 16.3. 2012, godkjent 26.10. 2012. Medisinsk redaktør Siri Lunde. 